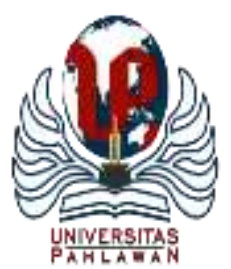

Edukatif : Jurnal Ilmu Pendidikan Volume 4 Nomor 1 Tahun 2022 Halm 185 - 194

EDUKATIF: JURNAL ILMU PENDIDIKAN

Research \& Learning in Education

https:/ledukatif.org/index.php/edukatif/index

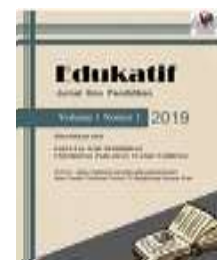

\title{
Implementasi Nilai dan Sikap Serta Semangat Entrepreneur untuk Memecahkan Masalah Sumber Daya Manusia di Sekolah
}

\author{
Nasyariah Siregar ${ }^{1 凶}$, Helty $^{2}$, Pitriyani $^{3}$, Firman $^{4}$ \\ Universitas Jambi, Indonesia ${ }^{1,2,3,4}$ \\ E-mail : nasyariahsiregar@uinjambi.ac.id ${ }^{1}$, heltyasafri@unja.ac.id ${ }^{2}$, yanipitri@gmail.com $^{3}$, \\ firman.fkip@unja.ac.id ${ }^{4}$
}

\begin{abstract}
Abstrak
Latar belakang penelitian yaitu untuk mengetahui implementasi nilai dan sikap serta semangat entrepreneur untuk memecahkan masalah sumber daya manusia di sekolah. tujuan dari penulisan yaitu untuk mendeskripsikan nilai dan sikap serta semangat entrepreneurship dalam pendidikan dan mendeskripsikan implementasi nilai dan sikap serta semangat entrepreneur untuk memecahkan masalah sumber daya manusia di sekolah. Metode penelitian ini adalah penelitian studi literatur. Hasil dan Pembahasan penelitian yaitu bahwa pendidikan yang berwawasan kewirausahan menjadi lebih bermanfaat dan akan memberikan peluang tumbuh dan berkembangnya kearah potensi kreativitas dan inovasi anak yang pada akhirnya pribadi yang memiliki karakter mandiri, kreatif, inovatif, bertanggung jawab, disiplin dan konsisten akan memilki kemampuan kewirausahaan. Esensi dari kewirausahaan adalah menciptakan nilai tambah di pasar melalui proses pengkombinasian sumber daya dengan cara-cara baru dan berbeda agar dapat bersaing. Implementasi nilai dan sikap serta semangat entrepreneur untuk memecahkan masalah sumber daya manusia di sekolah dapat dilakukan melalui kegiatan integrasi pada semua mata pelajaran, bahan ajar, kultur sekolah dan pengembangan diri.
\end{abstract}

Kata Kunci: Nilai, Sikap Semangat Entrepreneur, Sumber Daya Manusia

\begin{abstract}
The background of the research is to find out the implementation of values and attitudes as well as the entrepreneurial spirit to solve human resource problems in schools. The purpose of writing is to describe the values and attitudes and the spirit of entrepreneurship in education and to describe the implementation of values and attitudes and the entrepreneurial spirit to solve human resource problems in schools. This research method is literature study research. The results and discussion of the research are that entrepreneurship-oriented education becomes more useful and will provide opportunities for growth and development towards the potential for creativity and innovation of children who ultimately have independent, creative, innovative, responsible, disciplined, and consistent characters will have entrepreneurial abilities. The essence of entrepreneurship is to create added value in the market through the process of combining resources in new and different ways to compete. Implementation of values and attitudes and entrepreneurial spirit to solve human resource problems in schools can be done through integration activities in all subjects, teaching materials, school culture, and self-development.
\end{abstract}

Keywords: Values, Entrepreneurial Spirit Attitude, Human Resources

Copyright (c) 2022 Nasyariah Siregar,' Helty, Pitriyani, Firman

$\triangle$ Corresponding author:

Email : yanipitri0@gmail.com

DOI : https://doi.org/10.31004/edukatif.v4i1.1797

ISSN 2656-8063 (Media Cetak)

ISSN 2656-8071 (Media Online)

Edukatif : Jurnal Ilmu Pendidikan Vol 4 No 1 Tahun 2022 p-ISSN 2656-8063 e-ISSN 2656-8071 


\section{PENDAHULUAN}

Perkembangan zaman yang kian menantang mengakibatkan banyaknya pengangguran, kemiskinan, serta besarnya jumlah penduduk Indonesia yang tak diiringi kualitas sumber daya manusia, dan persaingan tenaga kerja ataupun ekonomi dari internasional. Sehingga pendidikan harus berperan aktif dalam menyiapkan sumber daya manusia dalam menghadapi tantangan zaman. Harapan untuk diterima di dunia kerja tentunya tidaklah keliru, tetapi tidak dapat dipungkiri bahwa kesempatan kerjapun sangat terbatas dan tidak berhubungan linear dengan lulusan lembaga pendidikan, baik pendidikan menengah maupun pendidikan tinggi (Yusuf \& Hamzah, 2016).

Menurut Schumpeter (Adinugraha, 2018) menyatakan bahwa entrepreneur mempunyai andil besar dalam pembangunan ekonomi melalui penciptaan inovasi, lapangan kerja dan peningkatan kesejahteraan. Kenyataannya dilapangan bahwa terjadi kesenjangan antara lapangan kerja dan lulusan institusi pendidikan. Pendidikan perlu menyiapkan generasi yang berjiwa tangguh, terampil serta kompeten, karena generasi masa depan tak hanya mencari atau menunggu pekerjaan namun dapat menciptakan lapangan kerja. Salah satunya ialah pendidikan yang berorientasi pada jiwa entrepreneurship (kewirausahaan). Pendidikan kewirausahaan bertujuan untuk membentuk SDM secara utuh (holistik), sebagai insan yang memiliki karakter, pemahaman dan keterampilan sebagai wirausaha.

Berdasarkan data yang dirilis oleh BPS pada tahun 2019, jumlah wirausahawan Indonesia pada usia produktif hanya 3.5\% dari jumlah penduduk dan angka ini masih tertinggal jauh jika dibandingkan dengan Negara-negara ASEAN lainnya seperti Singapura dengan persentase wirausahawan sebesar $7.2 \%$ serta Malaysia dan Thailand yang mencapai 5\% dan 5.1\%. Selain itu, data yang ditunjukkan oleh Entrepreneurship Global Index 2019 di mana Indonesia menduduki peringkat 97 dari 137 negara juga mencerminkan minat wirausaha yang masih rendah. Negara-negara maju ini memiliki jumlah entrepreneur rata-rata $14 \%$ bahkan lebih dari jumlah penduduk usia kerja. Dengan kata lain, semakin banyak jumlah entrepreneur di suatu Negara maka semakin tinggi pertumbuhan ekonomi. Oleh karena itu makalah ini membahas tentang implementasi nilai dan sikap serta semangat entrepreneur untuk memecahkan masalah sumber daya manusia di sekolah.

Pada penelitian ini membahas tentang konsep pendidikan entrepreneurship, nilai entrepreneurship, sikap entrepreneurship, semangat entrepreneurship, faktor yang mempengaruhi semangat entrepreneurship, pentingnya semangat entrepreneurship, sumber daya manusia di sekolah, kualitas sumber daya manusia dan implementasi nilai dan sikap serta semangat entrepreneur untuk memecahkan masalah sumber daya manusia di sekolah.

Penelitian terdahulu yang dilakukan oleh (Agustina, 2017) membahas tentang pendidikan mengenai nilai-nilai kewirausahaan, perkembangan anak sekolah dasar tingkat rendah, model Pendidikan dan pembelajaran kewirausahaan. Tidak membahas tentang konsep pendidikan entrepreneurship, sikap entrepreneurship, semangat entrepreneurship, faktor yang mempengaruhi semangat entrepreneurship, pentingnya semangat entrepreneurship, sumber daya manusia di sekolah, kualitas sumber daya manusia dan implementasi nilai dan sikap serta semangat entrepreneur untuk memecahkan masalah sumber daya manusia di sekolah.

Penelitian yang dilakukan oleh (Gusti, Palenti, \& Kusumawar, 2017) membahas tentang peran kewirausahaan sosial dalam meningkatkan entrepreneur, karakter, entrepreneur dan kewirausahaan social. Tidak membahas tentang, nilai entrepreneurship, semangat entrepreneurship, faktor yang mempengaruhi semangat entrepreneurship, pentingnya semangat entrepreneurship, sumber daya manusia di sekolah, kualitas sumber daya manusia dan implementasi nilai dan sikap serta semangat entrepreneur untuk memecahkan masalah sumber daya manusia di sekolah. Adapun tujuan dari penelitian ini yaitu untuk melihat pentingnya nilai dan sikap serta semangat entrepreneurship dalam pendidikan dan implementasi nilai sikap serta semangat entrepreneur untuk memecahkan masalah sumber daya manusia di sekolah. 
187 Implementasi Nilai dan Sikap Serta Semangat Entrepreneur untuk Memecahkan Masalah Sumber Daya Manusia di Sekolah - Nasyariah Siregar, Helty, Pitriyani, Firman

DOI: https://doi.org/10.31004/edukatif.v4i1.1797

\section{METODE PENELITIAN}

Metode penelitian ini adalah penelitian studi literatur. Menurut (Arikunto, 2013) metode penelitian studi literatur adalah serangkaian kegiatan yang berkenaan dengan metode pengumpulan data pustaka, membaca dan mencatat, serta mengelolah bahan penelitian. Jenis data yang dikumpulkan berupa data sekunder berupa hasil penelitian dari berbagai artikel, sumber pustaka dan dokumen yang sesuai dengan tema. Terdapat beberapa hal yang dilakukan oleh peneliti, yaitu (a) mengumpulkan literatur kemudian melakukan review terhadap beberapa istilah penting dalam penelitian. Beberapa literatur diperoleh dari berbagai sumber referensi. Istilah penting yang didefinisikan dalam penelitian ini adalah strategi pengembangan karakter entrepreneurship di sekolah, (b) mengumpulkan literatur hasil penelitian relevan. Hasil penelitian yang relevan diperoleh dan digunakan untuk memperkaya proses analisis, sehingga hasil analisis mampu memunculkan kesimpulan yang obyektif, (c) melakukan analisis secara mendalam berdasarkan semua literatur yang telah diperoleh dengan menyusun pembahasan. Pembahasan dilakukan untuk menyimpulkan tentang strategi pengembangan karakter entrepreneurship di sekolah, (d) menyusun kesimpulan berdasarkan hasil analisis. Kesimpulan yang diperoleh adalah pernyataan yang sesuai dengan tujuan penelitian, (e) mengajukan saran berdasarkan temuan-temuan yang diperoleh. Temuan-temuan yang diperoleh berdasarkan proses analisis dapat dijadikan sebagai masukkan, yang nantinya bermanfaat bagi peneliti maupun pembaca. Pengumpulan literatur ini dilakukan pada bulan November 2021. Pencarian menggunakan Google Cendekia. Artikel yang digunakan pada pembahasan penelitian ini berjumlah 3 artikel. Pertama, artikel atas nama Dwi Ampuni Agustina tentang model pembelajaran untuk mengenalkan kewirausahaan pada siswa sekolah dasar kelas rendah, Jurnal Bangun Rekaprima Volume 03 nomor 2 bulan Oktober tahun 2017. Kedua, artikel atas nama Ririn Gusti, Citra Dwi Palenti, dan Erma Kusumawardani, tentang kewirausahaan sosial dalam meningkatkan kemampuan enterpreneur pada mahasiswa pendidikan luar sekolah untuk menghadapi abad 21, jurnal Seminar Nasional Pendidikan Nonformal FKIP Universitas Bengkulu, Volume 1 Nomor 1 bulan Juli tahun 2017. Ketiga, artikel atas nama Septi Rostika Anjani, Hamdi Supriadi, Neneng Tita Amalya, Endah Mawarny, Ifa Nurmasari, tentang manajemen kewirausahaan dan meningkatkan kualitas sumber daya manusia, Jurnal LOKABMAS Kreatif Volume 02 Nomor 02 bulan Juli tahun 2021 Halaman 107-114.

\section{HASIL DAN PEMBAHASAN PENELITIAN}

\section{Konsep Pendidikan Entrepreneurship}

Entrepreneurship dalam pendidikan ialah kerja keras terus-menerus yang dilakukan pihak sekolah terutama kepala sekolah dalam menjadikan sekolahnya lebih bermutu. Sekolah sebagai ujung tombak dari output lulusan pendidikan, tentu ingin outcomes nya siswa yang mandiri yaitu bisa menghadapi tantangan dunia yang begitu cepat berubah dan memecahkan masalah yang terjadi dalam kehidupannya dengan baik. Hal ini tidak hanya pengetahuan yang bersifat kognitif saja melainkan ranah afektif. Jiwa entrepreneurship merupakan bagian dari ranah afektif perlu ditanamkan pada siswa sejak dini. Seorang individu harus berani mengembangkan usaha dan ide barunya untuk memperbaiki kualitas hidup yang diintergrasikan dalam pendidikan entrepreneurship di sekolah (Andayati, 2012).

Guru dan kepala sekolah harus mampu mengintegrasikan pembelajaran afektif (pendidikan kewirausahaan) dalam pembelajaran kognitif dengan berbagai pendekatan dan metode mengajar. Menurut $\mathrm{M}$. Scarborough \& Thomas W. Zimmerer (Basuki, 2007) mengemukakan karakteristik pendidikan entrepreneurship sebagai berikut: a. Desire for responsibility yaitu memiliki rasa tanggung jawab atas usahausaha yang dilakukannya dan selalu mawas diri. b. Preference for moderate risk yaitu lebih memilih resiko yang moderat, artinya ia selalu akan menghindari resiko baik yang terlalu rendah maupun yang terlalu tinggi. c. Confidence in their ability to success yaitu percaya akan kemampuan dirinya untuk berhasil. d. Desire for immediate feedback yaitu selalu menghendaki umpan balik. e. High level of energy yaitu memiliki semangat dan kerja keras untuk mewujudkan keinginannya demi masa depan yang lebih baik. f. Future orientation yaitu 
berorientasi kemasa depan, perspektif dan berwawasan jauh ke depan. g. Skill at organizing yaitu memiliki keterampilan dalam mengorganisasikan sumberdaya untuk menciptakan nilai tambah. $h$. Value of achievement over money yaitu lebih menghargai prestasi daripada uang.

Pendapat ini sejalan dengan yang dekemukakan oleh (Gusti, Palenti, \& Kusumawar, 2017) bahwa entrepreneurship merupakan gabungan dari kreativitas, inovasi dan keberanian menghadapi resiko yang dilakukan dengan cara kerja keras untuk membentuk dan memelihara usaha baru. Dari pandangan di atas dapat disimpulkan bahwa entrepreneurship adalah kemampuan dalam berfikir kreatif dan berperilaku inovatif yang dijadikan sebagai dasar, sumber daya, tenaga penggerak, tujuan siasat, kiat dan proses dalam menghadapi tantangan hidup.

\section{Nilai Entrepreneurship}

Kementerian pendidikan nasional menjabarkan nilai nilai entrepreneurship yang perlu diketahui dan dimengerti serta dapat diinternalisasi dalam diri setiap orang. Nilai nilai tersebut yaitu: mandiri, kreatif, berani mengambil resiko, berorientasi pada tindakan, kepemimpinan, kerja keras, jujur, disiplin, innovatif, tanggung jawab, kerjasama, pantang menyerah, komitmen, realistis, rasa ingin tau, komunikatif, dan motivasi kuat untuk sukses. Lebih rinci akan dipaparkan nilai dasar yang penting untuk dipegang dan dijadikan dasar bagi seorang entrepreneur antara lain: kreativitas, inovatif, berani menghadapi risiko, memiliki etika bisnis dan norma, serta semangat dan bertanggungjawab (Barthos, 2010).

Modal utama entrepreneur menurut Alma (Ruhana, 2012) adalah kreativitas, keuletan dan semangat bekerja. Semangat pantang menyerah ini memandang kegagalan hanya keberhasilan yang tertunda dan mereka tahan banting. Entrepreneur yang kreatif memiliki perhitungan cermat, mempertimbangkan segala fakta, informasi dan data. Seorang entrepreneur mampu memadukan apa yang ada di dalam hati, pikiran dan kalkulasi bisnis. Kreativitas adalah kemampuan untuk membuat kombinasi-kombinasi baru atau melihat hubungan-hubungan baru antara unsur, data dan variabel yang sudah ada. Kreativitas merupakan kemampuan seseorang untuk melahirkan sesuatu yang baru, baik berupa gagasan atau karya nyata, yang relatif berbeda dengan apa yang telah ada sebelumnya.

Kreativitas dan inovasi, menurut Kao (Islam, 2015) memiliki hubungan yang erat. Karena kreativitas artinya adalah kemampuan untuk memikirkan sesuatu yang baru dan berbeda, sedangkan inovasi merupakan kemampuan untuk melakukan, mengaplikasikan sesuatu yang berbeda. Dengan demikian, yang paling penting dalam entrepreneurship adalah kemampuan pengusaha untuk lebih kreatif dan memanfaatkan inovasi dalam kegiatan bisnisnya sehari-hari. Seorang pengusaha akan berhasil apabila ia selalu kreatif dan menggunakan kreativitasnya tersebut. Menurut Gwee (Kusumaningrum, Sumarsono, \& Gunawan, 2011) untuk menghadapi persaingan yang semakin kompleks dalam persaingan ekonomi global, maka kreativitas menjadi sangat penting untuk menciptakan keunggulan kompetitif dan kelangsungan bisnis.

Nilai-nilai dasar yang penting dalam entrepreneur antara lain: kreativitas, inovatif, berani menghadapi risiko, memiliki etika bisnis dan norma yang baik, serta bertanggungjawab dan memiliki disiplin diri. Menurut Hisrich (Mulyani \& Jamilus, 2021) ada beberapa nilai (value) yang bersifat umum yang dapat diamati sebagai karakteristik keberhasilan dalam entrepreneurship, yaitu: (1) Keinginan menghasilkan superior produk, (2) Layanan berkualitas terhadap konsumen, (3) Fleksibel, (4) Kemampuan dalam manajemen, (5) Memiliki sopan santun dan beretika, dan (6) Sikap seorang entrepreneur perlu selalu berusaha untuk menciptakan peluang bisnis dengan membangkitkan keberanian dan rasa bebas menciptakan sesuatu. Kreativitas dan inovasinya perlu dikembangkan untuk menciptakan peluang bisnis yang mendatangkan profit maupun benefit bagi dirinya maupun orang lain. Untuk membangkitkan kreativitas memerlukan suatu proses dengan langkahlangkah tertentu yaitu sebagai berikut: (1) Preparation, (2) Investigation, (3) Transformation, (4) Incubation, (5) Illumination, (6) Verification, (7) Implementation.

Seorang entrepreneur, menurut Yuyus (Nurseto, 2010) harus selalu menciptakan mimpi dan ide baru, jeli dalam memanfaatkan peluang, dan memanfaatkan potensi menjadi profit dan benefit secara efektif. Sifat 
seorang entrepreneur harus berani mengambil risiko yang telah diperhitungkan agar hasil yang diperoleh lebih besar daripada kegagalan dan sangat bergairah menghadapi tantangan. Menurut Hoffman (Saputra, 2015) tantangan baru ada artinya bagi seorang entrepreneur apabila terdapat risiko yang dapat diperhitungkan, yaitu dengan kriteria berikut: (1) Apabila mempengaruhi tujuan usaha yang ingin dicapai, (2) berarti bagi diri pribadi entrepreneur, (2) Kemampuan untuk mengendalikan diri pribadi entrepreneur, dan (3) Adanya suatu perasaan dan kepuasan kemungkinan dalam mengelola usaha untuk berhasil dan gagal. Kriteria dari suatu risiko menurut Leonardos (Adinugraha F. , 2018) mengandung potensi kegagalan dan potensi keberhasilan sehingga dapat dikelompokkan dalam tiga kelompok, antara lain: (1) Kelompok risiko tinggi, (2) Kelompok risiko rendah, dan (3) Kelompok risiko sedang.

Dari pembahasan diatas penelitian ini juga sejalan dengan yang dilakukan (Agustina, 2017) Instruksi Presiden Nomor 4 Tahun 1995 tentang Gerakan Nasional Memasyarakatkan dan Membudayakan Kewirausahaan, mengamanatkan kepada seluruh masyarakat dan bangsa Indonesia untuk mengembangkan program-program kewirausahaan. Integrasi pendidikan kewirausahaan yang dilakukan saat ini merupakan momentum untuk revitalisasi kebijakan Gerakan Nasional Memasyarakatkan dan Membudayakan Kewirausahaan. Pendidikan yang berwawasan kewirausahaan ditandai dengan proses pendidikan yang menerapkan prinsip-prinsip dan metodologi ke arah pembentukan kecakapan hidup (life skill) pada peserta didiknya melalui kurikulum terintegrasi yang dikembangkan di sekolah.

\section{Sikap Entrepreneurship}

Berikut adalah sikap-sikap yang dibutuhkan seseorang untuk menjadi seorang entrepreneur. 1. Ulet dan tidak mudah putus asa; Seorang wirausaha juga memiliki keuletan atau kegigihan dalam berusaha. Ia tidak akan berhenti dan puas begitu saja sebelum mencapai hasil yang diinginkannya. 2. Berani mengambil resiko; Setiap usaha selalu mengandung risiko mulai dari yang paling berat, seperti bangkrut atau rugi, maupun yang ringan seperti impas. 3. Memiliki rasa percaya diri yang tinggi; Rasa percaya diri menjadi sangat penting jika seseorang akan melangkah lebih jauh. Tanpa rasa percaya diri seorang akan ragu dan canggung dalam melangkah dan hal ini dapat berakibat fatal bagi usahanya. 4. Bersikap kreatif dan innovatif; Kreatif artinya kemampuan untuk berkarya dan berdaya cipta yang tinggi. 5. Berorientasi ke depan; Segala tindakan yang dilakukan sekarang selalu diarahkan untuk mencapai hasil yang tinggi di kemudian hari. 6. Memiliki kemampuan memimpin; Seorang wirausaha haruslah mampu menjadi pemimpin yang bertanggung jawab terhadap segala tugas, mampu melakukan pembagian tugas, mampu mengarahkan bawahan, mampu menjadi teladan bagi bawahannya, mampu membuat perencanaan sekaligus pengawasannya, dan aktivitas lain yang membutuhkan perannya sebagai pemimpin (Basuki, 2007).

Dalam konteks kewirausahaan menurut Andika dan Iskandarsyah (Delitasari \& Hidayah, 2017) menjabarkan bahwa menurut Gadaam sikap kewirausahaan yaitu kecenderungan untuk bereaksi secara afektif dalam menanggapi resiko yang akan dihadapi dalam suatu bisnis yang dapat diukur dengan skala sikap berwirausaha dengan indikator : a) tertarik dengan peluang usaha, b) berfikir kreatif dan inovatif, c) pandangan positif mengenai kegagalan usaha, d) memiliki jiwa kepemimpinan dan tanggung jawab, e) suka menghadapi resiko dan tantangan.

\section{Semangat Entrepreneurship.}

Pengertian Semangat Entrepreneurship dalah Melakukan pekerjaan dengan giat, sungguh-sungguh sehingga perkerjaan yang dilakukan dapat segera selesai dengan hasil yang maksimal adalah definisi dari semangat. Menurut Ayus dan Amir Hamzah dalam bukunya menerangkan definisi dari semangat entrepreneurship yang merupakan sikap ungggul, pantang menyerah, yang timbul dari dalam diri jiwa pemberani yang memiliki motivasi tinggi dalam dunia entrepreneur. Semangat entrepreneurship sangat berperan penting bagi seorang entrepreneur (Hastin \& Wandary, 2012). 
190 Implementasi Nilai dan Sikap Serta Semangat Entrepreneur untuk Memecahkan Masalah Sumber Daya Manusia di Sekolah - Nasyariah Siregar, Helty, Pitriyani, Firman

DOI: https://doi.org/10.31004/edukatif.v4i1.1797

Sebagai wirausaha (Entrepreneur) harus memiliki rasa semangat yang tinggi dalam berwirausaha. Orang yang memilki semangat yang tinggi adalah pekerja keras dan selalu bersedia untuk berupaya ekstra untuk meraih keberhasilan. Semangat entrepreneurship yang tinggi sebagai (karakteristrik kewirausahaan) dapat mendorong bahwa dalam dirinya ada potensi untuk bersikap mandiri dan membiasakan semangat bersungguhsungguh, ulet serta berkemauan untuk maju. Memutuskan untuk menjadi seorang entrepreneur bukanlah perkara mudah, berbagai pertimbangan dilakukan, selain meningkatkan kepercayaan diri atas usaha yang akan di jalankan juga membangun semangat entrepreneurship dari dalam diri sendiri (Islam, 2015).

Dengan semangat yang ada dalam diri seorang entrepreneur harus mampu tampil beda, penuh kreatifitas dan innovasi tiada henti. Dengan semangat juga seorang entrepreneur mampu menangkap peluang yang ada untuk dapat berhasil menjalankan usahanya dan menyingkirkan ketakutan akan resiko yang diganti dengan optimisme menggapai kesuksesan (Kurniawati, 2013). Dari urain diatas penulis berpendapat bahwa, semangat kewirausahaan merupakan suatu sikap atau perilaku seseorang dengan keseriusan, kegigihan, keuletan, dan kesungguhannya untuk melakukan segala sesuatu dengan ulet dan tekun demi mencapai keberhasilan dalam usahanya sesuai dengan sasaran dan tujuan. Seseorang dengan semangat kewirausahaanya akan siap dan sigap menghadapi segala resiko dan tantangan apapun untuk bisa mengembangkan usahanya.

\section{Faktor yang Mempengaruhi Semangat Entrepreneurship}

Ada beberapa factor yang mempengaruhi semangat wirausaha, diantaranya adalah pertama, keinginan meniru figur seseorang yang sukses. Meniru orang sukses bukan hanya sekedar mencari tahu resep sukses mereka, tetapi juga meniru semangat dan kerja keras mereka. Orang sukses adalah orang yang memiliki kepribadian positif, maka pelajari karakter positif mereka, yang membawa mereka pada kesuksesan. Kedua, rasa suka terhadap tantangan. Tantangan dalam hidup bukan merupakan hal yang harus dihindari, tetapi justru harus dihadapi dengan cerdas dan selalu berfikir positif. Karena melalui tantangan-tantangan tersebut kita ditempa untuk menjadi lebih tangguh. Ketiga, keinginan untuk tetap bertahan hidup (Mulyani \& dkk, 2010).

Hal ini merupakan naluri alamiah manusia, yaitu keinginan untuk mempertahankan hidupnya atau menyelamatkan hidupnya, karena keinginan untuk bertahan hiduplah maka kita harus selalu mengasah kemampuan berfikir untuk mengembangkan hal-hal baru. Keempat, keinginan untuk memperbaiki taraf hidup yang lebih baik lagi, dari yang dijalani. Manusia merupakan sosok yang memiliki kecerdasaan dan perasaan. Maka selain bertahan hidup, secara naluri manusia juga berkeinginan dan berusaha untuk membuat hidup lebih nyaman dan lebih baik. Kelima, kegagalan yang dialami dalam meniti karir pekerjaan. Kegagalan merupakan kesuksesan yang tertunda. Kita harus belajar dari kegagalan kita sehingga muncul semangat baru untuk lebih berhasil. Keenam, adanya cita-cita untuk menjadi pengusaha. Setiap manusia yang hidup pasti mempunyai cita-cita yang ingin digapai. Cita-cita tersebut merupakan harapan seseorang di masa yang akan datang, untuk mewujudkan cita-cita menjadi pengusaha, maka kita harus terus belajar dan berani berusaha (Nurseto, 2010).

\section{Pentingnya Semangat Entrepreneurship}

Kegagalan dalam berwirausaha adalah hal yang lumrah, jatuh bangun sebuah usaha adalah wujud dari semangat pantang menyerah yang dimiliki seorang entrepreneur. Banyaknya pengalaman dapat dijadikan guru atau sumber pembelajaran untuk bisa menjadi seorang entrepreneur yang sukses. Pengalaman yang dijalani dapat pula dijadikan motivasi untuk menyemangati diri agar dapat terus berinovasi. Umat muslim khususnya punya contoh hebat dalam bidang entrepreneurship, yaitu Rasulullah SAW yang dikenal sebagai seorang entrepreneur muda yang pernah berada pada masa masa sulis ketika berwirausahadan beliau melewati masa masa itu dengan penuh semngat pantang menyerah (Sudadio, 2016).

Beliau juga mampu memberikan dorongan semangat kepada para sahabatnya untuk tidak cepat berputus asa. Kemandirian adalaha semangat utama yang harus dimiliki dan menjadi dasar jiwa wirausaha. Seorang entrepreneur juga harus mampu melihat kesempatan dan peluang besar untuk melayani pasar. Seorang 
191 Implementasi Nilai dan Sikap Serta Semangat Entrepreneur untuk Memecahkan Masalah Sumber Daya Manusia di Sekolah - Nasyariah Siregar, Helty, Pitriyani, Firman

DOI: https://doi.org/10.31004/edukatif.v4i1.1797

entrepreneur selain bisa menyakinkan dirinya sendiri, juga harus menyekinkan orang lain tentang dirinya yang mempunyai hasrat dan semangat besar untuk dapat menjadi seorang entrepreneur.untuk dapat meraih itu semua selain semangat kejujuran dan ketekunam adalah modal yang wajib dimiliki oleh seorang entrepreneur.

Untuk mengembangkan semangat entrepreneurship kita perlu memiliki sikap berani dalam menghadapi kegagalan yang terjadi, motivasi tinggi untuk mengembangkan usaha, gairah kerja karena menyukai sebuah usaha dan apa yang dikerjakannya, serta imajinasi yang kuat untuk mengasah kreativitas dan inovasi untuk menentukan sebuah usaha yang mejanjikan dan bisa menuntun anda menuju jalan kesuksesan yang anda harapkan. Kreativitas adalah kemampuan untuk menciptakan ide-ide baru, menemukan cara baru untuk memahami problem-problem yang dihadapi dan memahami adanya peluang (Saputro, Achmad,, \& Handayani, 2016).

Sedangkan inovasi merupakan kemampuan untuk menerapkan ide baru atau memproduksi ide baru. Seorang entrepreneur yang suskes akan selalu menempuh saat-saat dimana ia harus bekerja keras membanting tulang dalam merintis usahanya. Untuk itu dengan semangat wirausaha yang kuat, daya juang dan sasaran tujuan yang tinggi adalah jalan bagi anda mewujudkan keberhasilan dalam menjalani usaha.

\section{Sumber Daya Manusia di Sekolah}

Definisi Sumberdaya Manusia Sumber Daya Manusia (SDM) mempunyai peranan yang sangat penting dalam pembangunan bangsa, sehingga untuk meningkatkan kualitas SDM diperlukan pendidikan. Tenaga pendidik dan tenaga kependidikan merupakan bagian dari salah satu sumber daya manusia Indonesia dan sekaligus merupakan aset bangsa yang akan mencetak insan yang cerdas dan bermartabat. Defenisi dari sumber daya manusia menurut Ndara dan Hasibuan (Yulianti \& Hartatik , 2014) pertama, manusia yang bekerja di lingkungan suatu organisasi (personil, tenaga kerja, pegawai atau karyawan), kedua, potensi manusiawi sebagai penggerak organisasi dalam mewujudkan eksistensinya, ketiga potensi yang merupakan asset dan berfungsi sebagai modal (non material) dadalam organisasi yang dapat diwujudkan menjadi potensi nyata secara fisik dan non fisik dalam eksistensi organisasi. Perkembangan ilmu pengetahuan dan teknologi yang semakin maju, diharapkan peran SDM khususnya pada lingkup lembaga Pendidikan.

Pengembangan SDM pada intinya diarahkan dalam rangka meningkatkan kualitasnya, yang pada gilirannya akan dapat meningkatkan produktivitas. Hasil berbagai studi menunjukkan, bahwa kualitas SDM merupakan faktor penentu produktivitas, baik secara makro maupun mikro. Sumber Daya Manusia (SDM) secara makro adalah warga negara suatu bangsa khususnya yang telah memasuki usia angkatan kerja yg memiliki potensi untuk berperilaku produktif (dengan atau tanpa pendidikan formal) yang mampu memenuhi kebutuhan hidup sendiri dan keluarganya yang berpengaruh pada tingkat kesejahteraan masyarakat di lingkungan bangsa atau negaranya (Yusuf \& Hamzah, 2016).

Pemaparan diatas juga sejalan dengan yang dilakukan (Gusti, Palenti, \& Kusumawar, 2017) pendidikan harus terus berikhtiar membangun generasi bangsa yang cakap secara intelektual, anggun secara moral, dan siap menghadapi tantangan zamannya. Pendidikan juga harus mampu melahirkan generasi bangsa yang memiliki jiwa dan pikiran besar untuk membangun negerinya. Di sisi lain, yang juga perlu disadari, pendidikan bukan tanggung jawab pemerintah/negara semata. Pendidikan sebagai jalan kemajuan negeri ini harus menjadi komitmen dan kesadaran bersama.

\section{Kualitas Sumber Daya Manusia}

Manusia merupakan sumber utama dalam dibutuhkan oleh organisasi bisnis (perusahaan) yang kedudukannya tidak mungkin tergantikan oleh apapun meskipun dengan teknologi yang mutakhir. Oleh karena itu, manusia (karyawan) dalam organisasi harus diperhatikan dan dikelola dengan baik agar kompetensi maupun keahliannya dapat ditingkatkan demi kelangsungan dan perkembangan organisasi secara keseluruhan. 
192 Implementasi Nilai dan Sikap Serta Semangat Entrepreneur untuk Memecahkan Masalah Sumber Daya Manusia di Sekolah - Nasyariah Siregar, Helty, Pitriyani, Firman

DOI: https://doi.org/10.31004/edukatif.v4i1.1797

Gronroos (Wijaya \& Harjanti, 2013) menyatakan bahwa kualitas terdiri dari 3 (tiga) komponen utama, yaitu: a. Technical quality; berkaitan dengan kualitas dari hasil (output) yang dipersepsikan pelanggan. b. Functional quality; berkaitan dengan kualitas dalam menyampaikan jasa (hasil pekerjaan). c. Corporation image; berkaitan dengan citra, reputasi dan daya tarik perusahaan secara umum. Kualitas sumber daya manusia adalah kemampuan sumber daya manusia untuk melaksanakan tugas dan tanggung jawab yang diberikan kepadanya berdasarkan latar belakang pendidikan, pelatihan yang diperoleh, pemahaman tentang tugasnya, kesiapan dalam melaksanakan perubahan dalam cara kerja dan penguasaan teknologi dan juga memiliki kesehatan yang prima Dengan kualitas sumber daya manusia yang mumpuni berintegritas tinggi akan menggiring pada hasil yang gemilang yang dapat di peroleh setiap organisasi.

\section{Implementasi nilai dan sikap serta semangat entrepreneur untuk memecahkan masalah sumber daya manusia di sekolah}

Berbicara Implementasi nilai dan sikap serta semangat entrepreneur di sekolah tentu tidak terlepas dari peran serta masyarakat sekolah itu sendiri. Sebagaimana kita ketahui pentingnya pelaksanaan pendidikan entreprenuership semenjak dini adalah untuk melakukan pembiasaan bagi peserta didik dalam memperoleh rasa kebermaknaan yang pada akhirnya akan membentuk pribadi yang berkarakter. Kepala sekolah, Guru, staf dan peserta didik merupakan satu kesatuan dalam sebuah struktur organisasi pada program pendidikan atau sekolah (Kusumaningrum, Sumarsono, \& Gunawan, 2011). Tentunya, kepala sekolah bertanggung jawab terhadap seluruh kegiatan yang berlangsung di sekolah tidak terkecuali dengan pengimplementasikan nilai dan sikap serta semangat entrepreneurship di dalamnya. Semua guru dituntut untuk mampu menginternalisasikan semua nilai tersebut dalam proses pembelajaran seperti, merencanakan, mendidik dan menilai peserta didik.

Machali (Delitasari \& Hidayah, 2017) menyatakan bahwa pendidikan entrepreneurship bertujuan untuk menyiapkan peserta didik serta lulusan yang berkarakter dan dapat mengembangkan potensi entrepreneurshipnya. Karakter yang dikembangkan adalah nilai-nilai entrepreneurship seperti kemandirian, keberanian, kreatif, berani mengambil resiko, berorientasi pada tindakan, kepemiminan, dan kerja keras. Hal ini selaras dengan tujuan pendidikan entrepreneurship yang menjadikan bangsa kreatif, berani, memiliki mental kewirausahaan, sehingga masalah ketenagakerjaan sedikit demi sedikit teratasi dan mempersiapkan peserta didik memiliki kecakapan hidup, berinteraksi dengan lingkungan sosial berdasarkan pertumbuhan dan lingkunganya.

Indonesia sebagai bangsa yang besar dituntut mengambil langkah besar dalam dunia pendidikan untuk mempersiapkan sumber daya manusia (SDM) yang berkualitas, memiliki kemandirian, kemampuan kerja, mampu beradaptasi, berkompetisi, memiliki kecakapan hidup (life skill) dan mampu membuka usaha/lapangan kerja sendiri. Semangat entrepreneurship tersebut hendaknya menjadi sebuah solusi dalam memecahkan masalah sumber daya manusia yang ada di sekolah. Sebelum kita membahas bagaimana implementasinya, terlebih dahulu penting untuk mengetahui apa itu sumber daya manusia (Nurseto, 2010).

Schermerhorn (Suharyadi \& dkk, 2008) yang mengemukakan bahwa "Human resource are the people, individuals, and groups that help organizations produce goods or services" yang artinya sumber daya manusia adalah orang-orang, individu-individu, dan kelompok-kelompok yang membantu organisasi menghasilkan barang-barang atau jasa-jasa. Pengertian tersebut menjadi landasan bahwa dalam mecapai tujuan dibutuhkan penggerak yang selalu bersinergi. Namun pada kenyataannya tidak semudah yang dibayangkan, tentu ada permasalah-permasalahan pada komponen SDM tersebut dalam proses perjalanannya. Melalui implementasi sikap, nilai dan semangat entrepreneurship inilah masalah SDM dapat kita temukan solusi yang diantaranya (Andayati D. , 2012).

Pertama, terintegrasi Pada Seluruh Mata Pelajaran Pengintegrasian pendidikan kewirausahaan dalam proses pembelajaran adalah penginternalisasian nilai-nilai kewirausahaan pada seluruh mata pelajaran yang ada di sekolah, sehingga tumbuh kesadaran akan pentingnya nilai-nilai, terbentuknya karakter wirausaha dan pembiasaan nilai-nilai kewirausahaan ke dalam tingkah laku peserta didik sehari-hari. Integrasi pendidikan 
193 Implementasi Nilai dan Sikap Serta Semangat Entrepreneur untuk Memecahkan Masalah Sumber Daya Manusia di Sekolah - Nasyariah Siregar, Helty, Pitriyani, Firman

DOI: https://doi.org/10.31004/edukatif.v4i1.1797

kewirausahaan di dalam mata pelajaran dilaksanakan mulai dari tahap perencanaan, pelaksanaan, dan evaluasi pembelajaran pada semua mata pelajaran (Suharyadi \& dkk, 2008). Nilai-nilai pokok kewirausahaan yang diintegrasikan ke semua mata pelajaran pada langkah awal ada enam nilai pokok yaitu: mandiri, kreatif pengambil resiko, kepemimpinan, orientasi pada tindakan dan kerja keras. Internalisasi nilai, sikap dan semangat kewirausahaam ini juga dilakukan pada kegiatan ekstrakurikuler dengan visi dan misinya adalah berkembangnya potensi, bakat dan minat secara optimal, serta tumbuhnya kemandirian dan kebahagiaan peserta didik yang berguna untuk diri sendiri, keluarga dan masyarakat.

Kedua, bahan Ajar Penginternalisasian nilai-nilai kewirausahaan dapat dilakukan ke dalam bahan ajar baik dalam pemaparan materi, tugas maupun evaluasi. Ketiga, kultur Sekolah Pengembangan nilai-nilai pendidikan kewirausahaan dalam budaya sekolah mencakup kegiatan-kegiatan yang dilakukan kepala sekolah, guru, konselor, tenaga administrasi ketika berkomunikasi dan menggunakan fasilitas sekolah dengan menginternalisasikan nilai dan sikap seperti kejujuran, tanggung jawab, disiplin, komitmen dan budaya berwirausaha di lingkungan sekolah (seluruh warga sekolah melakukan aktivitas berwirausaha di lingkungan sekolah) (Hastin \& Wandary, 2012).

Keempat, pengembangan Diri Kegiatan pengembangan diri merupakan upaya pembentukan karakter termasuk karakter wirausaha dan kepribadian peserta didik yang dilakukan melalui kegiatan pelayanan konseling berkenaan dengan masalah pribadi dan kehidupan sosial, kegiatan belajar, dan pengembangan karir, serta kegiatan ekstra kurikuler.

\section{KESIMPULAN}

Pendidikan yang berwawasan kewirausahan menjadi lebih bermanfaat dan akan memberikan peluang tumbuh dan berkembangnya kearah potensi kreativitas dan inovasi anak yang pada akhirnya pribadi yang memiliki karakter Mandiri, kreatif, inovatif, bertanggung jawab, disiplin dan konsisten akan memilki kemampuan kewirausahaan. Esensi dari kewirausahaan adalah menciptakan nilai tambah di pasar melalui proses pengkombinasian sumber daya dengan cara-cara baru dan berbeda agar dapat bersaing. Implementasi nilai dan sikap serta semangat entrepreneur untuk memecahkan masalah sumber daya manusia di sekolah dapat dilakukan melalui kegiatan sebagai berikut: 1. Integrasi pada semua mata pelajaran, 2. Bahan ajar, 3. Kultur sekolah dan 4. Pengembangan diri

\section{UCAPAN TERIMA KASIH}

Terimakasih kepada bapak Dr. Drs. Firman, M. Si Selaku dosen pengampu Mata Kuliah Entrepreneurship dalam Pendidikan. Terima kasih kepada EDUKATIF: JURNAL ILMU PENDIDIKAN Research \& Learning in Education Universitas Pahlawan yang telah bersedia menerbitkan jurnal.

\section{DAFTAR PUSTAKA}

Adinugraha, F. (2018, February). Media Pembelajaran Biologi Berbasis Ecopreneurship. Jurnal Ilmiah Pendidikan MIPA.

Agustina, D. A. (2017, Oktober). Tentang model pembelajaran untuk mengenalkan kewirausahaan pada siswa sekolah dasar kelas rendah. Jurnal Bangun Rekaprima , 3(2).

Arikunto, S. (2013). Prosedur Penelitian. Jakarta: Rineka Cipta.

Barthos, B. (2010). Manajemen Sumber Daya Manusia. Suatu Pendekatan Makro Cetakan ke 9. Jakarta: Bumi Aksara.

Basuki. (2007). Analisis hubungan antara motivasi, pengetahuan kewirausahaan, dan kemandirian usaha terhadap kinerja pengusaha pada kawasan industri kecil di daerah pulogadung. Jurnal Usahawan, 2(10), $1-8$. 
194 Implementasi Nilai dan Sikap Serta Semangat Entrepreneur untuk Memecahkan Masalah Sumber Daya Manusia di Sekolah - Nasyariah Siregar, Helty, Pitriyani, Firman

DOI: https://doi.org/10.31004/edukatif.v4i1.1797

Delitasari, I., \& Hidayah, N. (2017). Implementasi Pendidikan Entrepreneurship di SD Entrepreneur Muslim Alif-A Piyungan Yogyakarta. University Research Colloquium, 1-8.

Gusti, R., Palenti, C. D., \& Kusumawar, E. ( 2017, Juli). Tentang kewirausahaan sosial dalam meningkatkan kemampuan enterpreneur pada mahasiswa pendidikan luar sekolah untuk menghadapi abad 21. jurnal Seminar Nasional Pendidikan Nonformal FKIP Universitas Bengkulu, 1(1).

Hendro. (2011). Dasar-dasar Kewirausahaan. Jakarta: Erlangga.

Islam. (2015). Pengaruh Sikap Kewirausahaan, Norma Subyektif, dan Efikasi Diri terhadap Perilaku Berwirausaha Melalui Intensi Berwirausaha Mahasiswa. 3(1), 1-17.

Jain, M. (2012, 12). Social Entrepreneurship - Using Business Methods to Solve Sosial Problems: The Case of Kotwara, Decision. Social Entrepreneurship, 39(3).

Mulyani, \& Jamilus. (2021). Pengembangan Pendidik Sebagai Sumber Daya Manusia di Sekolah Menengah Atas. Edukatif: Jurnal Ilmu Pendidikan, 3(4), 1170 - 1176. doi:https://edukatif.org/index.php/edukatif/index

Mulyani, E., \& dkk. (2010). Pengembangan Pendidikan Kewirausahaan. Jakarta: Badan Penelitian dan Pengembangan Kurikulum.

Nurseto. (2010). Pendidikan berbasis entrepreneur. Jurnal Pendidikan Akuntansi Indonesia, 3(2), 52-59.

Qolb, S. K., \& Hamami, T. (2021, Universitas Pahlawan tuanku Tambusai Riau). Impelementasi Asas-asas Pengembangan Kurikulum terhadap Pengembangan KurikulumPendidikan Agama Islam. Edukatif: Jurnal Ilmu Pendidikan, 3(4), 1120 - 1132. doi:https://edukatif.org/index.php/edukatif/index

Ruhana, I. (2012, Juni). Pengembangan Kualitas Sumber Daya Manusia vs Daya Saing Global. Jurnal Profit, $6(1), 50-56$.

Saputra, K. (2015). Pendidikan Berbasis Entrepreneurship. Yogyakarta: DIVA Press.

Saputro, E., Achmad, N., \& Handayani, S. (2016). Identifikasi Faktor yang Mempengaruhi Sukses Wirausaha. Benefit, Jurnal Manajemen dan Bisnis, 1(1), 34-41.

Sudadio. (2016, Februari). Implementasi Model Pembelajaran Berbasis Entrepreneurship dalam Rangka Pembentukan Jiwa Entrepreneur pada Mahasiswa Jurusan Pendidikan Luar Sekolah FKIP UNTIRTA. University of Sultan Ageng Tirtayasa, 1(1), 1-10.

Suharyadi, \& dkk. (2008). Kewirausahaan, Membangun Usaha Sukses Sejak Usia Muda. Jakarta: Salemba Empat.

Wijaya, Y. H., \& Harjanti, D. (2013). Enterpreneurial Leadership dan Hubungannya dengan Kinerja Bisnis pada Usaha Mikro Kecil di Wilayah Jawa Timur. AGORA, 1(3).

Yulianti, \& Hartatik . (2014, September). Pentingnya Media Pembelajaran Berbasis Enterpreneurship. Jurnal Pemikiran dan Pengembangan SD, 1(4), 283-287.

Yusuf, A. A., \& Hamzah, A. (2016). Pengaruh Kepercayaan Diri dan Semangat Kewirausahaan Terhadap Minat Menjadi Wirausaha. Al-Amwal: Jurnal Ekonomi dan Perbankan Syari'ah, 8(2). 